\title{
Smiljana (Smiljka) Nell, (Zagreb, 23. listopada 1931. - Zagreb, 28. srpnja 2021.) - Širina interesa i predanost u službi sestrinstva
}

\section{Smiljana (Smiljka) Nell, (Zagreb, October 23, 1931-Zagreb, July 28, 2021) - Width of interest and devotion to the service of nursing}

\author{
Gordana Kičin Ercegovac \\ Klinika za infektivne bolesti „Dr. Fran Mihaljević“, glavna sestra Odjela za opću infektologiju s dnevnom bolnicom
}

\begin{abstract}
Sažetak
Smiljana (Smiljka) Nell rođena je 23. listopada 1931. godine u Zagrebu kao jedino dijete obitelji Nell. Osnovnu školu završila je u Zagrebu te je nakon položene male mature upisala gimnaziju. Uz gimnaziju završila je i srednju glazbenu školu. Po završetku gimnazije upisala se u Školu za medicinske sestre u Mlinarskoj ulici u Zagrebu, gdje je diplomirala 1950. godine. Nakon diplome počinje raditi u Klinici za infektivne bolesti „Dr. Fran Mihaljevič" u Zagrebu. Dvije godine kasnije upisala je poslijediplomski studij za medicinske sestre u Školi narodnog zdravlja u Zagrebu i diplomirala sestrinstvo u javnom zdravstvu. Pravni fakultet Sveučilišta u Zagrebu upisala je 1977. godine kao izvanredni student te je odslušala predmete s prve godine. Od 1968. do 1988. godine (do odlaska u mirovinu) bila je glavna sestra Klinike za infektivne bolesti „Dr. Fran Mihaljević“. Smiljka Nell bila je inicijator osnivanja i prva predsjednica Sekcije sestara infektoloških odjela Socijalističke Republike Hrvatske (danas Hrvatska udruga medicinskih sestara, Infektološko društvo). Sekcija je osnovana u Zagrebu 1969. godine, a Smiljka Nell obavljala je dužnost predsjednice od 1969. do 1973. godine nakon čega obnaša dužnost tajnice Društva medicinskih sestara i tehničara SR Hrvatske, do 1975. godine. U njezinu mandatu održana su prva tri Savjetovanja sestara infektoloških odjela i klinika Socijalističke Republike Hrvatske. Bila je član uređivačkog odbora Vjesnika medicinskih sestara i medicinskih tehničara SR Hrvatske od 1970. do kraja 1973. godine. Smiljka Nell učinila je velik iskorak u unapređenju sestrinstva, a posebice organizacije rada infektoloških odjela cijele Hrvatske te je sve do odlaska u mirovinu, krajem 1988. godine, zbog svih svojih aktivnosti smatrana vrlo utjecajnom medicinskom sestrom u području skrbi za infektološke bolesnike. Preminula je 28. srpnja 2021. godine.
\end{abstract}

Ključne riječi: Smiljana (Smiljka) Nell, Infektološko društvo Hrvatske udruge medicinskih sestara, Klinika za infektivne bolesti „Dr. Fran Mihaljević“, povijest sestrinstva

\begin{abstract}
Smiljana (Smiljka) Nell was born on 0ctober 23, 1931 in Zagreb as the only child of the Nell family. She finished elementary school in Zagreb, and after passing the matriculation exam, she enrolled in high school. Along with high school, she also finished music high school. After graduating from high school, she enrolled in the School for Nursing in Mlinarska Street in Zagreb, where she graduated in 1950. After graduation, she began to work at the Clinic for Infectious Diseases "Dr. Fran Mihaljević" in Zagreb. Two years later, she enrolled in postgraduate studies for nurses at the School of Public Health in Zagreb and graduated in public health nursing. In 1977, she enrolled at the Faculty of Law, University of Zagreb, as a part-time student and attended the first year. From 1968 to 1988 (until her retirement), she was the head nurse of the Clinic for Infectious Diseases "Dr. Fran Mihaljevic'". Smiljka Nell was the initiator of the establishment and the first president of the Section of Nurses of Infectious Diseases of the Socialist Republic of Croatia (today Infectious Diseases Society of the Croatian Nurses Association). The section was founded in Zagreb in 1969. Smiljka Nell served as president from 1969 to 1973, when she became the Secretary of the Association of Nurses and Technicians of the Socialist Republic of Croatia, until 1975. During her tenure, the first three Conferences of Nurses of Infectious Diseases Departments and Clinics of the Socialist Republic of Croatia were held. She was a member of the editorial board of the Journal of Nurses of Croatia from 1970 to the end of 1973. Smiljka Nell made a significant contribution in improving nursing, especially in improving the organization of infectious diseases departments throughout Croatia, and until her retirement at the end of 1988, she was considered a very influential nurse in the field of care for infectious diseases patients. She died on July 28, 2021.
\end{abstract}

Keywords: Smiljana (Smiljka) Nell, Infectious Diseases Society of the Croatian Association of Nurses, Clinic for Infectious Diseases "Dr. Fran Mihaljević", history of nursing

\section{Djetinjstvo i školovanje}

Smiljana (Smiljka) Nell rođena je 23. listopada 1931. godine u Zagrebu u bolnici Merkur kao jedino dijete obitelji Nell. Njezin otac Vjekoslav rođen je u Senju, a majka Marija rođena je u Hrvatskom zagorju. Otac je radio u Pošti u Jurišićevoj ulici u Zagrebu kao viši poštanski tehničar, a majka je ondje bila radnica. Treći i četvrti razred osnovne škole završila je u Osnovnoj školi Ivana Filipovića u Zagrebu u Zajčevoj ulici školske godine 1940./1941. i 1941./1942. s vrlo dobrim uspjehom te odličnog i pohvalnog vladanja [1, 2]. U te dvije godine pohađala je predmete: Nauk vjere, Hrvatski ili 
srpski jezik, Povijest, Zemljopis, Računstvo s mjerstvom, Poznavanje prirode, Praktična znanja i vještine, Nauk o zdravlju, Kućanstvo i ženski ručni rad, Crtanje, Pisanje, Pjevanje i Gimnastika. U to je vrijeme živjela u Zajčevoj 50. Prema primjedbi napisanoj u njezinoj dokumentaciji, pretpostavlja se da je 15. srpnja 1942. upisala Osnovnu školu Augusta Harambašića te tamo pohađala peti i šesti razred [2]. Nakon osnovne škole položila je malu maturu [1]. U kojoj je školi pohađala prvi i drugi razred, nije poznato.

Osnovna škola Ivana Filipovića u Zagrebu, tada Lašćinska gradska niža pučka obospolna škola, sagrađena je 1903. kao osma škola u Zagrebu. Izgrađena je prema tadašnjim modernim pedagoškim i higijenskim načelima na obroncima Florijanskog puta (danas Zajčeva ulica) okružena vrtom i voćnjakom. Zgrada je imala četiri učionice. Prva školska godina 1903./1904. započela je 1. rujna. Zbog povećanog broja učenika 1905. godine dograđuje se istočni dio školske zgrade s još četiri učionice. Od tada škola nije mijenjala svoj izgled. Tijekom I. i II. svjetskog rata školska zgrada pretvorena je u vojnu bolnicu, a nastava se u ratnim uvjetima održavala u drugim školskim zgradama i u prirodi kad su vremenske prilike to dopuštale. Tijekom Domovinskog rata nastava se s manjim prekidima odvijala u zgradi škole. Kontinuitet rada u ovoj staroj školi već više od jednog stoljeća nikada nije prekidan [3].

Osnovna škola Augusta Harambašića osnovana je 1913. godine kao Državna mješovita pučka škola u Harambašićevoj ulici te je iste godine započela s radom u novoj zgradi u kojoj su bile 4 učionice (po dvije na svakoj etaži). Zbog povećanja broja razrednih odjeljenja, već 1921. godine završena je nadogradnja drugog dijela zgrade u kojem su dograđene još 4 učionice, po 2 na svakoj etaži. Tom dogradnjom zgrada škole dobila je današnji izgled. Uz školu je nadograđena sportska dvorana koja je građena dvije godine, a njezina izgradnja nije bila završena kad je 20. svibnja 1941. godine školsku zgradu i dvoranu zaposjela njemačka vojska. Za to vrijeme, sve do 1944. godine, nastava se održavala u zgradama škola na Lašćini i u Jakićevoj te u privatnim kućama u Harambašićevoj 50 i Njegoševoj 5 [4, 5].

Nakon osnovne škole Smiljana Nell upisala je klasičnu gimnaziju u Križanićevoj ulici u Zagrebu [1].

Klasična gimnazija - Collegium Zagrabiense, najstarija je srednja škola u Republici Hrvatskoj koja kontinuirano djeluje od svojega osnutka. Utemeljili su je isusovci 3. lipnja 1607. godine. Danas je zagrebačka Klasična gimnazija smještena u zgradi koja je sagrađena u svrhu njezina preseljenja 1932. godine u ulicu Jurja Križanića 4 a [6].

Na poticaj oca, uz gimnaziju je završila i srednju glazbenu školu. Voljela je svirati klavir i čitati, uživala je u slušanju klasične glazbe te je imala široko znanje o slikarstvu. Tečno je govorila engleski i francuski jezik, a služila se i njemačkim jezikom. Po završetku gimnazije upisala je Školu za liječničke pomoćnike u Mlinarskoj ulici u Zagrebu', gdje je diplomirala 1950. godine. Prema svjedočanstvu obitelji bila

\footnotetext{
1 Škola za medicinske sestre Mlinarska taj je naziv nosila od 1949. do 1952. godine. Promjena naziva škole i samog naziva medicinske sestre u liječnička pomoćnica izazvao je veliko nezadovoljstvo među medicinskim sestrama.
}

je najbolja učenica u generaciji. Nakon završetka škole započela je svoj radni vijek u Klinici za infektivne bolesti „Dr. Fran Mihaljević" u Zagrebu² na II. odjelu, gdje je obavljala posao glavne odjelne sestre. Dvije godine kasnije upisala je poslijediplomski studij za medicinske sestre u trajanju od tri semestra u Školi narodnog zdravlja u Zagrebu te diplomirala sestrinstvo u javnom zdravstvu [1]. Cilj poslijediplomskog studija bio je podići stručnost medicinskih sestara u području opće i specijalne njege pacijenata, dijetetike i patronaže i osposobljavanje za rad u javnom zdravstvu i nastavi [7]. Pravni fakultet Sveučilišta u Zagrebu upisala je 1977. godine i kao izvanredni student odslušala predmete na prvoj godini studija [8].

\section{Rad u Klinici za infektivne bolesti „Dr. Fran Mihaljević"}

Od 1968. pa do odlaska u mirovinu 1988. godine bila je glavna sestra Klinike za infektivne bolesti „Dr. Fran Mihaljević".

Tijekom epidemije velikih boginja 1972. godine sudjelovala je u najmasovnijem cijepljenju koje je obuhvatilo više od 18 milijuna stanovnika bivšeg SFRJ-a. Bila je na studijskom putovanju u Londonu i posjetila je Institut Pasteur u Parizu [1, 9].

U Vjesniku se u jednom od izvještaja navodi: ...da je Izvršni odbor Saveza društva medicinskih sestara i medicinskih tehničara Hrvatske posebnu pažnju posvetio stručnom usavršavanju članova Društva putem organiziranja stručnih putovanja s ciljem razmjene iskustva. Tako je u dva navrata organizirano stručno putovanje u London s ukupno 82 sudionika. Međutim, u izvještaju se ne spominju imena medicinskih sestara i nije navedeno koje su godine stručna putovanja bila organizirana [10].

U svrhu sprečavanja nastanka bolničkih infekcija, organizirala je i provodila stručne sastanke medicinskih sestara. Organizirala je predavanja za medicinske sestre pripravnice i obavezno polaganje internog ispita znanja. Takav način edukacije u Klinici se provodi i danas [9, 11, 12].

Sve do odlaska u mirovinu, zbog svih svojih aktivnosti, Smiljka Nell smatrana je vrlo utjecajnom medicinskom sestrom u području skrbi za infektološke bolesnike [1, 11, 12].

\section{Doprinos u radu Hrvatske udruge medicinskih sestara ${ }^{3}$}

Smiljka Nell bila je inicijator osnivanja te prva predsjednica Sekcije sestara infektoloških odjela SR Hrvatske.

\footnotetext{
${ }^{2}$ Klinika za infektivne bolesti „Dr. Fran Mihaljević“ do 1970. godine nosila je naziv Bolnica za zarazne bolesti, od 1970. do 1978. godine Klinika za zarazne bolesti, a od 1978. godine nosi današnji naziv.

${ }^{3}$ Hrvatska udruga medicinskih sestara (HUMS) mijenjala je nazive, što joj je i bila pravna obaveza, prilikom promjene naziva države. U opisanom razdoblju od 25. svibnja 1953. godine nosi naziv Društvo diplomiranih sestara Narodne Republike Hrvatske. Od 1962. do 1977. nosi naziv Društvo medicinskih sestra i tehničara SR Hrvatske. Društvo 1977. godine mijenja organizacijsku strukturu i do 1992. godine nosi naziv Savez društva medicinskih sestara i tehničara SRH $[16,17]$.
} 


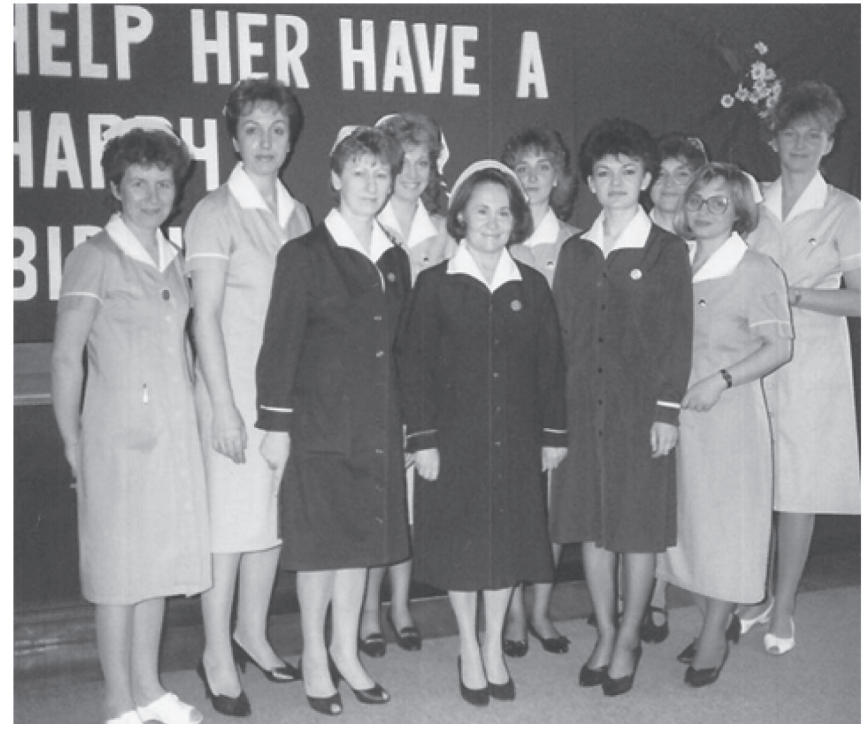

SLIKA 1. Klinika za infektivne bolesti „Dr. Fran Mihaljević", Zagreb. Međunarodni dan sestrinstva 1987. godine. Slijeva nadesno: prvi red: Nensi Brnin, Smiljka Nell, Katica Pejić, Štefica Ranogajec; drugi red: Kata Jurić, Jela Knežević, Štefanija Kutleša, Jasminka Vinković, Ana Jozić, Mirica Turk. Izvor: Pismohrana Infektološkog društva HUMS-a, Photo: anonimno

Sekcija je osnovana u Zagrebu 1969. godine, a Smiljka Nell obavljala je dužnost predsjednice od 1969. do 1973. godine. Od 1959. do 1969. godine infektološke medicinske sestre sudjelovale su na brojnim edukacijama koje su provedene u organizaciji Infektološke sekcije Zbora liječnika Hrvatske (ZLH) $[12,13,14,15]$.

Smiljka Nell učinila je velik iskorak u unapređenju sestrinske prakse, posebice na unapređenju organizacije rada infektoloških odjela cijele Hrvatske.

U njezinu mandatu održana su prva tri Savjetovanja sestara infektoloških odjela i klinika SR Hrvatske ${ }^{4}$.

Prvo savjetovanje pod nazivom Nozokomijalne infekcije održano je 6. - 8. lipnja 1969. godine u Varaždinu. Prisustvovalo je 56 medicinskih sestara iz Republike Hrvatske, Infektivne klinike u Skopju, Splošne bolnice u Celju, Klinike za infektivne bolesti u Beogradu, Infektivne klinike u Sarajevu, Medicinskog centra u Zenici i Infektivnog odjela Opšte bolnice u Tuzli. Osim sestara koje rade na infektološkim odjelima sudjelovale su sestre iz Ginekološkog odjela u Varaždinu, Bolnice „Dr. M. Stojanović" u Zagrebu ${ }^{5}$, Dječjih jaslica u Karlovcu, Dječjeg odjela Opće bolnice u Osijeku, Kirurškog odjela medicinskog centra u Slavonskom Brodu, Medicinskog centra u Zenici, Tuberkuloznog odjela u Pakracu i Internog odjela Medicinskog centra u Pakracu. Istovremeno se i održavao sastanak Sekcije infektologa ZLH-a pa su sestre osim

\footnotetext{
${ }^{4}$ Sekcija je tijekom vremena mijenjala naziv. Od 1992. godine nosi naziv Infektološka sekcija Hrvatskog udruženja medicinskih sestara, od 1993. godine Hrvatsko infektološko društvo medicinskih sestara i medicinskih tehničara. Do 2003. godine Infektološka sekcija HUMS-a, a od 2003. godine do danas Infektološko društvo HUMS-a [9].

${ }^{5}$ Danas Klinički bolnički centar Sestre Milosrdnice, Zagreb
}

na svojem sastanku, održale predavanja i time sudjelovale i na liječničkom skupu.

Drugo savjetovanje održano je 8. - 9. prosinca iste godine u Zagrebu u Bolnici za zarazne bolesti i u Školi medicinskih sestara u Zagrebu u Mlinarskoj 34 pod nazivom Intenzivna. Prisustvovale su 44 medicinske sestre iz Republike $\mathrm{Hr}$ vatske, Srbije, Bosne i Hercegovine, a prisustvovao je i velik broj medicinskih sestara koje ne rade na infektološkim odjelima. Medicinske sestre aktivno su sudjelovale i na sastanku Infektološke sekcije ZLH-a koji se istovremeno odvijao. Nakon stručnog dijela organiziran je posjet tvornici Pliva $[13,14]$.

Treće savjetovanje održano je 12. studenog 1970. godine u Zagrebu u predavaonici Bolnice za zarazne bolesti u suradnji s Infektološkom sekcijom ZLH-a [13, 18].

$\mathrm{Na}$ Četvrtom savjetovanju medicinskih sestara Jugoslavije, održanom od 27. do 28. listopada 1972. godine, Smiljka Nell bila je jedna od triju članova Komisije za zaključke savjetovanja $[19,20,21]$.

Bila je i član uređivačkog odbora Vjesnika medicinskih sestara i tehničara Hrvatske od 1970. do 1973. godine. U tom je razdoblju u Vjesniku objavila nekoliko članaka $[21,22,23$, 24].

Od 1973. do 1975. godine bila je prva tajnica Društva medicinskih sestara i medicinskih tehničara SR Hrvatske ${ }^{6}$ [20].

Smiljka Nell 17. svibnja 1977. godine u Zagrebu je preuzela Zahvalnicu koju je Savez društava medicinskih sestara i tehničara SR Hrvatske dodijelio Infektološkoj sekciji za njezin predani rad [26].

\section{Nagrade i priznanja}

Na proslavi 50. godišnjice rada Saveza društava medicinskih sestara i tehničara SR Hrvatske u Zagrebu, 23. studenog 1979. godine uručena joj je zlatna značka za: „rad na očuvanju zdravlja čovjeka s naročitim osvrtom na njegu bolesnika, doprinos na stručno-društvenoj afirmaciji zvanja medicinske sestre, organizaciji stručne sekcije pri Društvu sestara, aktivno sudjelovanje u izobrazbi mladih sestara kao i učenica medicinskih škola te za pisanje i objavu mnogih stručnih radova koji su od velikih vrijednosti za zvanje." [26, 27].

Smiljka Nell dobila je od kolektiva Klinike za zarazne bolesti Priznanje za rad 1973. godine. Priznanje je u obliku pravokutne pločice bakrene boje $s$ ukoso odrezanim lijevim gornjim kutom. Grb grada Zagreba iz XV. stoljeća nalazi se na prednjoj strani, a posveta na stražnjoj strani.

Na posveti piše: 1923-1973. GOD., KZZB ODAJE PRIZNANJE ZA RAD NELL SMILJKI. KOLEKTIV KLINIKE.

Dobitnica je Ordena rada sa srebrnim vijencem, ali je nepoznat podatak o godini dodjele. [1]. Ovo odlikovanje dodjeljivalo se pojedincima, organizacijama udruženog rada, drugim organizacijama i jedinicama oružanih snaga SFRJ-a

\footnotetext{
${ }^{6}$ Izvršni odbor Društva medicinskih sestara i medicinskih tehničara SR Hrvatske sastojao se od predsjednika, potpredsjednika, prvog tajnika, drugog tajnika, blagajnika i deset članova.
} 
koji su postigli iznimne uspjehe u privredi, te za rad od osobitog značenja za napredak zemlje u ostalim društvenim djelatnostima [28].

Zahvaljujući sestri Smiljki Nell, Infektološko društvo aktivno djeluje već 52 godine kao najstarije društvo Hrvatske udruge medicinskih sestara.

Svojim primjerom cjeloživotnog rada na sebi kroz široku opću naobrazbu i stalnu profesionalnu znatiželju, Smiljka Nell prikazala je sestrinstvo kao umjetnost koja iziskuje posvećenost i veliku širinu duha.

\section{Literatura/References}

[1] Karmen Žižek, usmeno svjedočanstvo zabilježila Gordana Kičin Ercegovac 27. studenog 2019. i 26. rujna 2021. Pismohrana Infektološkog društva HUMS-a

[2] Pismohrana Osnovne škole Ivana Filipovića. Smiljana Nell.

[3] Osnovna škola Ivana Filipovića Zagreb: Povijest. Dostupno na: http:// os-ifilipovica-zg.skole.hr/skola/povijest (pristup: 8. studenog 2021.)

[4] Osnovna škola Augusta Harambašića Zagreb. Povijest. Dostupno na: http://www.os-aharambasica-zg.skole.hr/skola/povijest?cal_ ts $=804549600$ (pristup: 16. studenog 2021.)

[5] HR-DAZG-195 Državna mješovita pučka škola u Harambašićevoj ulici. Državni arhiv u Zagrebu. Dostupno na: http://www.daz.hr/vodic/sit /article/hr-dazg-195-drzavna-mjesovita-pucka-skola-u-harambasicevoj-ulici (pristup: 16. studenog 2021.)

[6] Klasična gimnazija u Zagrebu. Wikipedija. 2021. Dostupno na: https:// hr.wikipedia.org/wiki/Klasi\%C4\%8Dna_gimnazija_u_Zagrebu (pristup: 10. studenog 2021.)

[7] Topolić Šestan I. Povijesni razvoj sestrinstva u RH. Diplomski rad. Sveučilište u RIJECl fakultet zdravstvenih studija Sveučilišni diplomski studij. Sestrinstvo - menadžment u sestrinstvu. 2020: 18. Dostupno na: https://zir.nsk.hr/islandora/object/fzsri\%3A1038/datastream/ PDF/view (pristup: 15. studenog 2021.)

[8] Nell S. Index pravnog fakulteta Sveučilišta u Zagrebu. 1977. Pismohrana Infektološkog društva HUMS-a

[9] Pismohrana Infektološkog društva HUMS-a

[10] Canciani S. Izvještaji. Vjesnik društva medicinskih sestara i tehničara Hrvatske. 1975; 13 (3): 192-4.

[11] Anonimno. Izvještaj o radu za 1988. godinu. Sekcija sestara infektoloških odjela SR Hrvatske. Pismohrana Infektološkog društva HUMS-a

[12] Mandica Rukavina, Katica Matijević, Božica Pavlinić, usmeno svjedočanstvo zabilježila Gordana Kičin Ercegovac 9. lipnja 2018. Pismohrana Infektološkog društva HUMS-a

[13] Pismohrana Infektološke sekcije Zbora liječnika Hrvatske (danas Hrvatsko društvo za infektivne bolesti Hrvatskog liječničkog zbora)

[14] Nell S, Pavlinić B. Izvještaji sa savjetovanja. Vijesnik društva medicinskih sestara i tehničara Hrvatske. 1970; 8 (2): 72.

[15] Anonimno. Zapisnik s Pete redovite izborne skupštine Saveza medicinskih sestara i tehničara SR Hrvatske. Izvještaji predsjednica sekcija.

\section{Zahvala}

Autorica zahvaljuje Mandici Rukavina, Katici Matijević, Božici Pavlina i Karmen Žižek na pruženim informacijama o sestri Smiljani (Smiljki) Nell. Također zahvaljuje profesorici Sandi Franković na pomoći i savjetima prilikom pisanja članka.

\section{Nema sukoba interesa}

\section{Authors declare no conflict of interest}

Vijesnik medicinskih sestara i med. tehničara SR Hrvatske. 1985.; XXIII (5-6): 177-8.

[16] Franković S. Poznavanje povijesti kao izvor zajedništva u sestrinstvu. Dostupno:https://voxfeminae.net/pravednost/sanda-frankovic-poznavanje-povijesti-kao-izvor-zajednistva-u sestrinstvu/ učitano: 13. studenog 2021.)

[17] Franković S., Abou Aldan D., Ostojčić N. Početak profesionalnog udruživanja medicinskih sestara u Republici Hrvatskoj. Sestrinski glasnik, 2020; 25 (1): 17-21.

[18] Anonimno. Vijesti. Vijesnik društva medicinskih sestara i tehničara $\mathrm{Hr}$ vatske. $1971 ; 9$ (1): 46

[19] Nell S, Radonić K, Kralj Š. Zaključci četvrtog savjetovanja medicinskih sestara Jugoslavije. Vijesnik društva medicinskih sestara i tehničara Hrvatske - psihijatrijska njega. 1973; 11 (2, 3 i 4): 183-4.

[20] Anonimno. Vjesnik medicinskih sestara i tehničara Hrvatske. 1975; 13 (2):71, 92

[21] Anonimno. Društvo medicinskih sestara i tehničara Hrvatske. Izvještaj o radu Izvršnog odbora društva za razdoblje od 1973. do 1975. Vjesnik medicinskih sestara i tehničara Hrvatske.1977; 15 (1): 191.

[22] Nell S, Bezjak A, Knezetić I. Uloga medicinske sestre u sprečavanju hospitalnih infekcija. Vjesnik medicinskih sestara i medicinskih tehničara. Psihijatrijska njega. 1972; 10 (2): 98-102.

[23] Nell S. 50. godišnjica sestrinstva u SR Hrvatskoj. Dodjela nagrada medicinskim sestrama. Vijesnik društva medicinskih sestara i tehničara Hrvatske. 1971; 9 (4): 15.

[24] Nell S, Pavlinić B. Vjesnik društva medicinskih sestara i tehničara $\mathrm{Hr}$ vatske. 1970; 8 (1): 1.

[25] Nell S. Nozokomijalne infekcije. Vjesnik društva medicinskih sestara i tehničara Hrvatske. 1970; 8 (2): 51-60.

[26] Anonimno. Izvještaji. Zapisnik s I. sjednice predsjedništva Saveza društva medicinskih sestara-tehničara SR Hrvatske. Vijesnik društva medicinskih sestara i tehničara Hrvatske. 1979; 17 (5): 194.

[27] Anonimno. 50. objetnica rada Saveza društava medicinskih sestaratehničara SRH. Vijesnik društva medicinskih sestara i tehničara SR Hrvatske. 1979; 18 (6): 1980; 18 (1): 4-13.

[28] Orden rada. Wikipedija. 2013. Dostupno: https://hr.wikipedia.org/ wiki/Orden rada (pristupljeno: 10. studenog 2021.) 